\title{
Ergological Perspectives for the Use of Driving Simulators
}

\author{
Thiago Drumond Moraes ${ }^{1}$ \\ Department of Social Psychology and Development, Federal University of Espirito Santo, \\ Vitória, ES, Brazil \\ Yves Schwartz \\ Institute d'Ergologie, Université d'Aix-Marseille, Aix-en-Provence, France \\ Centre d'EPistémologie et d'ERgologie Comparatives - Centre National de la Recherche \\ Scientifique, Aix-en-Provence, France
}

\begin{abstract}
Despite controversial Brazilian legislation on simulation-based driver training, it is used only rarely. Furthermore, there is no requirement to use it in professional road driver training. According to the international literature, in which the subject has been studied for a much longer period, there is still insufficient evidence to justify the widespread use of simulators to train professional drivers. However, this literature contains no critical analysis of the effects of the theoretical and methodological foundations utilised in this training. To contribute to this debate, we review the literature on simulation-based training for professional drivers, critically analysing it through the contributions of Ergology and French Professional Didactics. We note some problems with the different training programmes examined: (a) no recognition of the actual activity being simulated or the socially constructed knowledge that is necessary to perform it; (b) an insufficient conception of the skills and knowledge mobilised in work situations; and (c) a failure to understand a professional activity. We present alternative methods of using simulation-based training for professional drivers: collective training mediated by simulation and based on the knowledge, norms, and values shared by drivers.
\end{abstract}

Keywords: Driving simulators, transport, professional training, Ergology.

\section{Perspectivas Ergológicas para o Uso de Simuladores de Direção}

\section{Resumo}

Apesar da controversa legislação brasileira sobre formação por simuladores de direção, seu uso ainda é escasso. Além disso, não há obrigatoriedade de seu emprego em formação de condutores rodoviários profissionais. Segundo a literatura internacional, onde o assunto é estudado há mais tempo, ainda não há evidência suficiente que justifique o amplo uso de simuladores em formações de condutores profissionais. Por outro lado, não se observa nessa literatura uma análise crítica dos efeitos dos fundamentos teórico-metodológico utilizadas nessas formações. Visando contribuir para esse debate, revisamos a literatura sobre uso de simuladores em formações de condutores rodoviários profissionais, analisando-a

Mailing address: Federal University of Espírito Santo, Department of Social Psychology and Development, Cemuni VI, campus Goiabeiras, Av. Fernando Ferrari, 514, Goiabeiras, Vitória, ES, Brazil 29075-910. Phone: (27) 4009-2505. E-mail: thiago.moraes@ufes.br and yves.schwartz@univ-amu.fr

Funded by the Coordination for the Improvement of Higher Education Personnel - CAPES (Recipient: Thiago Drumond Moraes, grant no. BEX 2103/14-1) and the Espírito Santo Research Support Foundation (FAPES). 
criticamente a partir das contribuições da Ergologia e da Didática Profissional francesa. Observamos problemas nas formações experimentadas: (a) não reconhecimento da atividade real a simular e dos saberes socialmente construídos necessários para executá-la; (b) concepção insuficiente sobre competências e saberes mobilizados em situação de trabalho; (c) incapacidade de apreensão de uma atividade profissional. Apresentamos alternativas para uso de simuladores nas formações de condutores profissionais: formações coletivas mediadas pela simulação e em torno de saberes, normas e valores partilhados pelos condutores.

Palavras-chave: Simuladores de direção, transporte, formação profissional, Ergologia.

\section{Perspectivas Ergológicas para el Uso de Simuladores de Conducción}

\section{Resumen}

A pesar de polémica legislación brasileña sobre formación de simuladores de conducción, su uso es escaso. Además, no se obliga su uso en formación de conductores profesionales. En la literatura internacional, donde el tema es pesquisado hace mucho tiempo, no existe evidencia suficiente para justificar el uso generalizado de simuladores en formaciones de conductores profesionales. Sin embargo, no se observa en esta literatura un análisis crítico de los efectos de los fundamentos teóricos y metodológicos utilizadas en estas formaciones. Contribuyendo a este debate, se revisa la literatura sobre uso de simuladores en formación de conductores profesionales, analizando-as críticamente a partir de contribuciones de la Ergología y de la Didáctica Profesional francesa. Observamos problemas en la formación pesquisadas: (a) no reconocimiento de la actividad para simular y de los saberes socialmente construidos necesario para la realizar la actividad; (b) concepción insuficiente sobre saberes y competencias movilizados en situaciones de trabajo; (c) incapacidad de aprehender una actividad professional. Presentamos alternativas para uso de simuladores en formación de conductores profesionales: formaciones colectivas mediadas por simulación y alrededor de saberes, normas y valores compartidos por los conductores.

Palabras clave: Simuladores de conducción, transporte, formación profesional, Ergologia.

Professional training involves different methodological strategies, including simulation (Abbad, Zerbini, Carvalho, \& Meneses, 2006). Although simulation-based training is not new, new information technologies have driven its use in the most diverse fields of professional training, including for road transport workers (Blanco, Hickman, Hanowski, \& Morgan, 2011).

There are many ways of designing and using simulations that reflect the theoretical assumptions underlying their uses (Pottier, 2013). Simulations are often accompanied by technological aids and instruments that are typically conceived as simulators. Although their versatility is highly valued (Blanco et al., 2011), simulators and simulation are often only used for training with a body-kinaesthetic learning style (Castro \& Ferreira, 2006).
Simulation and simulators have been gaining a privileged space in different areas of professional training, but the most well-established use of simulators may perhaps be found in the field of health and in airline pilot training (Goode, Salmon, \& Lenné, 2013). In contrast, in the field of road transport, which is the sector that is responsible for the largest number of work accident deaths in many developed and developing countries (Mooren, Grzebieta, Williamson, Olivier, \& Friswell, 2014; Santana, Nobre, \& Waldvogel, 2005), the use of professional simulators is not yet widespread, despite its recent growth (Blanco et al., 2011; Moraes, 2016).

There are a number of reasons why simulators are not used to train road transport workers, including the absence of any scientific evidence of their benefits, the high cost of purchasing 
these instruments without a proven financial return, and a shortage of instructors who are qualified to effectively use simulation techniques and properly operate simulators (Grüneberg \& Schröder, 2012). These reflections are the result of studies on the legislative uses and appropriations of these instruments in professional training that has been conducted over nearly the past 15 years in developed countries (Directive 2003/59/EC, 2003). In Brazil, only recently has there been a political debate on the systematic introduction of this technology in road transport driver training (Resolução Conselho Nacional de Trânsito ${ }^{\circ}$ 493, 2014; Resolução Conselho $\mathrm{Na}$ cional de Trânsito $\mathrm{n}^{\circ}$ 543, 2015). Although the national legislation indicates the optional use of simulators for training drivers in general, it indicates nothing about training professional drivers. Should similar resolutions for these drivers be developed, as in the aforementioned European resolution?

The successful use of simulators for training aviation and health workers has not in fact been observed when training road transport workers. Thus, it is necessary to question the reasons for this relative failure, emphasising the economic aspects (Grüneberg \& Schröder, 2012; Moraes, 2016). However, in addition to the factors noted by these authors, we demonstrate another factor that limits the possible benefits of using simulators to train professional drivers: The current uses of this instrument are limited by the theoretical conceptions that underlie them, which contributes to reducing their effects. To help evaluate the (in)adequacy of using simulators in professional training, we perform an analysis of the international literature on simulation-based professional training, investigating the theoretical conceptions that are used in training programmes and the extent to which these conceptions expand or limit their impact. Therefore, we critically analyse the ways in which simulators have been used for training in countries where these practices are older and/or more common.

We conduct the literature review based on the perspectives of Ergology (Schwartz, 2012; Schwartz \& Durrive, 2010) and Professional Didactics (Pastré, 2011). Both perspectives share some conceptions that are crucial for understanding the potential use of simulators: (a) socially shared knowledge, more or less related to socially instituted knowledge, is produced in all professional activities; and (b) this knowledge is created through the active engagement of workers - with their history, their debates on norms, and their values - in professional practice and in concrete work situations. Therefore, learning occurs in the activity rather than through it. Without taking this point into consideration, the effective use of simulators will be limited to very specific situations, such as laboratory situations.

To conduct the literature review, we use texts that have been published in scientific journals, conference annals, books, and research reports funded by governmental and non-governmental agencies. We present a summary of the main results found, followed by some critical analyses mobilised by the theoretical references cited. We emphasise that the use of the term simulators will hereafter refer to driving simulators designed for professional drivers.

\section{Main Results Found in Publications on Simulation-Based Professional Driver Training}

Most of the studies were conducted with fixed-base simulators, a $180^{\circ}-270^{\circ}$ visual field, virtual mirrors, and realistic control devices (steering wheel, gears, pedals, etc.). However, the results obtained in the studies were less related to the type of simulator used and more to the relationship between the characteristics being trained and the training programme's design (Brock, Jacobs, Van Cott, McCauley, \& Norstrom, 2001; Moraes, 2016).

Laboratory studies that develop and test simulators confirm their ability to encourage the learning of certain skills, such as basic vehicle control, parking manoeuvres for unloading, and fuel efficiency (Dorn \& Stannard, 2006; Uhr, Felix, Williams, \& Krueger, 2003). There are indications, in studies with variable quality, that the man-machine interaction facilitates learning and that this learning improves if the training is more tailored (Tarr, 2005) or if the 
instruments are better suited to their objectives (Tarr \& Whitmire, 2008). Given that these laboratory studies have not been replicated in realworld situations, we can question their validity for guiding the use of simulators in actual training programmes. However, some studies have evaluated the effectiveness of simulation-based training in real organisations, partly confirming its potential to replace and/or complement the traditional on-the-road (in real-world situations) and behind-the-wheel (in real vehicles) training because it shows similar performance in terms of learning transfer (Morgan et al., 2011), is positively evaluated by users (Neukum, Lang, \& Krueger, 2003; Reed, Parkes, Peacock, Lang, \& Rehm, 2007), facilitates faster learning (Lindsey \& Barron, 2008), or demonstrates an effective skills transfer, particularly in terms of learning about fuel efficiency (Reed et al., 2007; Strayer \& Drews, 2003). However, because the studies are not longitudinal, to date, the long-term effects of simulation-based training have not been investigated.

The training programmes used regularly by companies that transport products and/or people have been positively evaluated by the users, whether they are learners (Aginaga-Garcia, Iriarte-Goni, Pintor-Borobia, Ros-Ganuza, \& San Miguel-Indurain, 2013), instructors, or directors of road transport industries (Brock et al., 2001; Reep, Staes, \& Perk, 2013). The following observations were also made: In the case of fuel efficiency training, there was a gain in the driver's economic performance, with improvements of $4.5 \%$ to $6.1 \%$ (Kihl, Herring, Wolf, Finn, \& Yang, 2007); for learners, the simulated response of the controls is more important than how closely these controls physically resemble the real controls (Brook-Carter, Luke, \& Parkes, 2004); and the type of simulator can influence learning performance, which means that companies must be aware of which skills they need to train before purchasing training simulators (Brock et al., 2001). There is no evidence that training with these instruments reduces accidents (Goode et al., 2013; Grüneberg \& Schröder, 2012), although one publicationwith no reliable scientific verification-suggests that this training programme reduced accidents by $5.9 \%$ (Edson, 2003). Although these publications showed evidence of learning transfer to real-world situations, this evidence has no solid support in objective or unquestionable data; companies are unaccustomed to carefully recording this information, and their poor records make evaluation more difficult (Kihl, Herring, Wolf, McVey, \& Kovuru, 2006).

In summary, simulators are potentially interesting instruments, but the set of texts investigated did not show sufficient evidence that they are a better instrument, more suitable and economically viable than traditional professional driver training (Moraes, 2016). Grüneberg and Schröder (2012) note that, although they are interesting, there are still no data that confirm that there is any compensation for the heavy investment in purchasing, preparing, and maintaining training simulators, which casts a shadow on their future. However, an American study has shown large cargo transport companies making systematic use of these instruments (Morgan et al., 2011), although this study refers to the period prior to the 2008 housing crisis, which may have altered this picture.

\section{Uses of Simulators in Professional Training}

To the extent that a training practice should be anchored in theories about learning, knowledge, and activity and that these theories influence the different uses of simulators (Pottier, 2013), it is important to determine which theories have been referenced in the literature. Although few texts highlight the theoretical grounds that guide their practices, a careful analysis allowed us to deduce some of their foundations.

\section{Skills Evaluated}

Many skills are trained and/or verified using simulators. Those investigated most frequently concern vehicle handling: for novices learning basic control (keeping the vehicle in the lane; negotiating curves; parking in reverse, in difficult situations or with special cargo) or for novice and experienced professionals developing advanced 
vehicle control, such as appropriate reactions in situations that are experienced only rarely (e.g., a burst tyre; Morgan et al., 2011) or refreshing their memory for work in specific and seasonal weather (the beginning of the winter season for snowplough drivers; Kihl et al., 2007; Strayer \& Drews, 2003; Tarr, 2005). It is also necessary to drive safely (active and passive safe driving) and economically (ecological and economically efficient driving). Brazilian resolutions on driving simulators also refer to these same skills.

In general, simulators tend to be designed as substitutes for a real vehicle in kinaesthetic driver training (Moraes, 2016; Morgan et al., 2011). There is little research on skills that are less related to vehicle handling but that are part of professional driving tasks, such as 'communication tasks', 'non-technical collective skills', 'supplementary steering tasks', and 'general planning for driving and the tasks to be performed'. Although these tasks are not as necessary for regular Class B drivers, who are the object of Brazilian resolutions, they play a very important role for professional drivers (Valot, 2007).

Only two studies suggest that simulators may train the psychomotor and affective aspects that are involved in driving, although they provide no empirical evidence (Bonch-Bruevich, Kremez, \& Chirkov, 2010; Navarrete, Urquiza, Hernandez, \& Madrid, 2004). However, some studies present training programmes that address driver attitudes towards safe and/or economical driving (Reed et al., 2007; Tarr \& Whitmire, 2008), which indicates the nascent inclusion of affective reactions in simulation-based training programmes. Although some theoretical texts indicate a greater diversity of skills that can be taught by simulators, they present no correlated empirical studies, which is a sign of the gap between the instrument's possibilities and the empirical experiments that have been conducted.

\section{User Attitudes}

Learners evaluate simulators differently according to their expertise. Less experienced drivers place greater importance on the use of the equipment and are more satisfied with it (Kihl et al., 2006; Morgan et al., 2011). More experienced workers assess simulation-based training as interesting but do not believe that it is compatible with reality because of the simulators' lack of operational control, because some operating controls do not emit the necessary sensory cues to properly manage the vehicle (Kihl et al., 2006), or because the training programme overstates the frequency of incidents that are relatively rare in real-world situations, which, according to the workers, makes the simulation experience fairly unrealistic (Morgan et al., 2011). Although the aforementioned Brazilian resolutions refer to the training of novice drivers, those planning continuing training with professional drivers should consider the assessments of more experienced professionals to make the use of simulators more effective.

\section{Theoretical, Epistemological, and Methodological Assumptions}

Few studies note the theoretical, epistemological, and methodological assumptions that underlie the uses, analyses, and development of simulation-based training. When present, these comprise brief references to models that refer more to the behavioural and cognitive levels of skills than to the psycho-affective and attitudinal dimensions of driving, such as the models of Rasmussen (1983; Blanco et al., 2011; Brock et al., 2001; Morgan et al., 2011; Victor et al., 2011), Michon (1985; Kihl et al., 2006; Neukum et al., 2003), and Bloom (Navarrete et al., 2004). Michon's and Rasmussem's cognitive models have many common characteristics, although the former has been proposed to explain driver behaviour and the latter to explain operator behaviour in work incidents. Both establish three levels of skills and vehicle/machinery control. The level of vehicle control (Michon) or skills (Rasmussen) refers to automated behavioural patterns - with a response time in milliseconds intended to ensure operational control of the vehicle/machinery at a pre-conscious level, requiring few cognitive resources to resolve incidents. The level of manoeuvres (Michon) or rules (Rasmussen) refers to more or less sequential and schematic actions, triggered when there is evidence that the automatic schemas are partially 
insufficient for managing the situations encountered or when negotiating the vehicle's relationship to other vehicles on the road, using more or less standardised solutions, requiring more cognitive resources and more time than the previous level. The strategic (Michon) and the knowledge levels (Rasmussen) refer to planning routes and searching for solutions to unexpected problems that are not necessarily known or automated, and they operate over a long and constant period of time, requiring many cognitive resources. Note that neither model addresses the driver's affective dimension; this dimension is only briefly addressed in the authors' text referring to Bloom's taxonomy, a more general model of skills and human learning. We also observed that none of the texts discussed social and cultural aspects or the values that underlie driving behaviours, neither of which has been addressed by the main models used in the aforementioned studies.

Additionally, little about the methods used is described. The general training course design is sometimes presented, typically utilising a theoretical and practical design (classrooms + simulators) in the following sequence: a classroom introduction to the subject, a practical exercise in the simulator, followed by a performance evaluation mediated by the instructor (Reed et al., 2007; Strayer \& Drews, 2003). This system is most commonly found in shorter training programmes that are specific to a certain skill. In other cases, the training programme combines simulator training with practice in real vehicles (classrooms + simulators + real vehicles; Aginaga-Garcia et al., 2013; Lindsey \& Barron, 2008; Morgan et al., 2011). This procedure, which is also recommended by the Brazilian resolutions, is more common when training professionals who are entering the profession. The differences in course design vary greatly depending on the scenarios to be simulated. In the case of complex scenarios, which mobilise very specific and focused skills for experienced drivers and involving risky situations, for reasons of safety and practicality, the procedures that are adopted in simulators tend not to be replicated in real life. In the case of courses for beginners, data indicate that real vehicles must be used in training (Mor- gan et al., 2011). The possibility that simulationbased training will completely replace real vehicles has yet to be proven, although the results of the latter study seem to frustrate expectations, at least for initial training programmes. On the other hand, in the studies investigated, this instrument is only used to train certain specific professional driving skills (Moraes, 2016).

Regarding methodological perspectives, the most frequently cited are analysing the driving via feedback and debriefing, analysing any errors, and demonstrating examples with a nonpunitive attitude (Blanco et al., 2011; Reep et al., 2013; Victor et al., 2011); progressive and developmental learning (Bonch-Bruevich et al., 2010; Reep et al., 2013; Romoser \& Hirsch, 2012); repetitions of exercises and tasks, varying scenarios for the development of a single skill (Aginaga-Garcia et al., 2013; Goode et al., 2013; Uhr et al., 2003); and exercises based on performance in simulators, indicating tailored learning (Bonch-Bruevich et al., 2010; Tarr \& Whitmire, 2008). Simulators are also designed as instruments for verifying performance and evaluating training needs (Reep et al., 2013; Tarr \& Whitmire, 2008; Victor et al., 2011), but there are rare cases when they are used more playfully, such as those based on games (Bonch-Bruevich et al., 2010), or in training that involves collective analysis (Lang, Diels, Grüneberg, \& Helmchen, 2011), reinforcing the idea that some potential uses remain unexplored.

\section{Role of Instructors}

Although instructors are important to the success of simulation-based training (Kihl et al., 2006; Reed et al., 2007), we found no systematic discussion of what role they should play in the training programmes developed and/or evaluated. The following aspects were recognised as important: their enthusiasm for the instrument; their evaluation, documentation, and attitude of openness and acceptance towards their students' performance; their continual feedback to learners; their attitude of confidence, emotional support, honest criticism, and ability to promote individual and collective reflections and engagement; and their encouragement of critical ex- 
changes regarding common experiences and lessons among learners (Blanco et al., 2011; Kihl et al., 2007; Reed et al., 2007; Victor et al., 2011). However, there is little clarity regarding how to train instructors (Morgan et al., 2011; Reep et al., 2013), given that employing instructors who are not prepared to use simulators does not necessarily produce good training results (Lang et al., 2011). These authors also found that debriefing is a fundamental methodological ally to effective training.

Few studies note the dimensions of collective learning as an element that is encouraged by the simulator (Goode et al., 2013; Lang et al., 2011; Neukum et al., 2003). Some studies emphasise the importance of instructors as a valuable source of experience for novices (Kihl et al., 2006; Morgan et al., 2011), but this dimension receives only peripheral attention. Although socially produced and shared knowledge emerges from the activity, it tends not to be an object of intervention in simulation-based professional training.

\section{Some Analyses}

Based on this review, we can draw some preliminary conclusions. If the use of simulators is to become more widespread, then there are some problems that must be considered. First, there are the costs. Although it is economically viable, given that the high costs of purchasing and installing the equipment are offset by the savings on training expenses and its benefits (Morgan et al., 2011), the initial investment value is still a stumbling block. Second, many workers experience simulator sickness during training, reducing the instrument's effectiveness. Moreover, for its use to be successful, it requires institutional support, training methods that are well-integrated with the other methods originally used in the organisation, and a team of well-trained instructors, which are all elements that are not easily mobilised in complex organisations.

On the other hand, it seems to us that the theoretical, epistemological and methodological assumptions regarding the uses of simulators also contribute to this gap. Based on research with simulators in the medical field, Pottier (2013) suggests that different theoretical approaches to learning lead to different uses of the instrument. The behaviourist approach advocates using simulators as an exercise for body training by repeating different sections of the simulation, mediated by positive and negative reinforcements that are mobilised by the instructor. From the constructivist perspective, simulators become ways to propose problems that allow new knowledge and skills to be assimilated and accommodated to the previous schema. The social perspective, which partially integrates the constructivist approach, advocates for simulators as an opportunity, both for sharing knowledge among agents and for collective reflection on teamwork and cooperative learning based on the interdependence of different professions. From its different viewpoints, the humanistic perspective suggests that simulators - which typically include self-evaluation modules - can and should be used autonomously by users, with or without support from tutors, thus providing self-directed learning that is grounded in intrinsic motivation factors, through a constant oscillation between experimenting with, reflecting on, and applying the concepts developed. In addition to these models cited by Pottier (2013), we found that Professional Didactics advocates for using simulators based on problem-solving, as in the constructivist approach, but combines this perspective with debriefing that is based on collective analysis of the activity (Pastré, 2005), bringing it closer to a social perspective.

Making this distinction, we found that the publications and studies that discuss professional training in road transport, even if not explicitly, approach the use of simulators from a primarily behaviourist conception, with behavioural and corporeal training as the main objectives (e.g., Reep et al., 2013; Victor et al., 2011). A few seem more in line with constructivist perspectives, suggesting scenarios that gradually adapt to the users' knowledge (e.g., Bonch-Bruevich et al., 2010; Romoser \& Hirsch, 2012). Simulators are very rarely used as recommended by humanistic perspectives, which suggests the possibility of an autonomous and independent manipula- 
tion of the instrument by the student (Romoser $\&$ Hirsch, 2012). Two studies suggest training in pairs, one of which advocates training that involves collective skills (Lang et al., 2011; Neukum et al., 2003), as recommended by the social perspective. No studies use problem-solving, which is a central strategy for both the constructivist perspective and Professional Didactics, not even in analysing the activity. It should also be noted that, according to the publications cited, the simulated scenarios do not necessarily refer to the actual work activity, nor are they produced based on analyses of the task or activity, with few exceptions (Mitsopoulos-Rubens, Lenné, \& Salmon, 2013a).

We observed that the equipment is often more highly valued than the training programme's design. For example, although there are a number of publications that propose models for classifying simulators (e.g., Brock et al., 2001; Eryilmaz, Tokmak, Cagiltay, Isler, \& Eryilmaz, 2014; Goode et al., 2013), few reflect on the epistemological assumptions that are present in different training programmes (Lang et al., 2011). Because the use of simulators depends less on their technological development and more on the compatibility between the skills that are to be trained and what the equipment seeks to develop (Brock et al., 2001), placing the primary focus on the instrument - rather than its method of use - may reveal an underlying notion that technological capacity is what gives rise to training effects. This also indicates disregard for a debate that, in practice, may create difficulties when trying to combine these instruments with already existing training methods (MitsopoulosRubens, Lenné, \& Salmon, 2013b; Neukum et al., 2003; Reep et al., 2013). For this reason, Mitsopoulos-Rubens et al. (2013b) suggest returning to the theoretical discussion on the uses of simulators as a strategy for improving their potential.

Hence, there are some other provisional conclusions: (a) there are no major justifications for investing in simulators (Grüneberg \& Schröder, 2012); (b) they are promising instruments, in spite of everything (Moraes, 2016); (c) their uses are limited by the theoretical and epistemological references that underlie them; (d) there are different possibilities for their uses based on other references; and (e) more research on the subject is necessary.

The results of this literature review could discourage the use of simulators because it has provided no sufficient evidence of their effectiveness. We have chosen a different path; inspired by the French experiences of Professional Didactics (Pastré, 2011), which uses simulation as one of the pillars of its practices (Pastré, 2005), we discuss points 3 and 4 listed above, suggesting that the results found in this review are perhaps problems related more to the uses of simulators than to their potential because the theoretical and epistemological dimensions that could propose new ways of using the instrument have not been valued highly enough. To accomplish this task, we use the theoretical and philosophical perspective of Ergology (Schwartz, 2012; Schwartz \& Durrive, 2010) as a point of support.

\section{Ergological Criticism of the Uses of Simulators}

For Ergology (Schwartz, 2012), human activity (whether it is related to work or not) can never be fully anticipated or predicted because a person will inevitably make changes to what has been anticipated. These changes stem from efforts to reconcile - through the activity itself - the requirements and impositions that precede the action (what is called antecedent norms) with the inconsistencies and incompatibilities that are found in the environment, in objects, in other individuals with whom the person interacts, in norms, and in the person's own conditions, amidst conflicting values that existed before the action. In this effort, there is an attempt to transform the environment in which the person acts into his/her own environment, recentering it on him/herself and his/her actions and needs (Schwartz, 2004; Schwartz \& Echternacht, 2009).

Simulation-based training is still an activity, even though the simulated activity is not the same as what it seeks to simulate. Thus, it follows that 
it is impossible to fully grasp the instrument's potential and problems that are based only on its design and the conceptions and prescriptions that are implicit in it (in a word, its anticipations), even if we consider that its qualities and characteristics somehow influence its possibilities of use. The potential of simulators is amplified by the reinventions that are made, with it, by users during their everyday uses. The unforeseen usabilities created by users may suggest new uses for simulators and promising results in training with these instruments. However, if we find that not even the use of regular vehicles in training situations has proven effective for improving performance or reducing accidents (Christie, 2001; Helman, Grayson, \& Parkes, 2010), then it is impossible to hold only the instrument itself responsible for the quality of professional training. Thus, the ideal simulator is not one that is technically closer to a real vehicle - either in appearance or because it elicits user behaviour that is similar to what real vehicles elicit - but rather one that is functionally related to the training objectives (Goode et al., 2013). However, based on the central considerations of Ergology, it is necessary to question - from the learners' perspective - whether the training objectives would correspond to the needs that are imposed by the actual activity or to the needs of managers and instructors, who are generally focused on the logic of anticipations that, as we have observed, is never fully implemented.

We have observed elsewhere that more experienced learners criticise the realism of simulators and that inexperienced learners value training in which there is an exchange of experience with veterans and instructors (Kihl et al., 2006; Neukum et al., 2003). This aspect suggests three problems that are present in this training programme but that apply to all of those presented in this review: (a) no recognition of which actual activity - and thus which socially shared knowledge - to simulate in simulators and training programmes (i.e., an incompatibility of training objectives); (b) an insufficient theoretical and epistemological conception of what the skills and knowledge present in a work situation are; and (c) how to understand a work activity. We discuss each of these points according to the assumptions of Ergology, seeking to identify the limits of simulators and to present new perspectives. Ultimately, we present some possibilities for applying simulators that result from this reflection.

\section{No Recognition of the Actual Activity}

Studies on professional training that are based on an evaluation of needs or tasks (Grüneberg \& Schröder, 2012; Mitsopoulos-Rubens et al., 2013a; Tarr \& Whitmire, 2008) or on the development of simulators and training programmes (Dorn \& Stannard, 2006; Lindsey \& Barron, 2008) almost exclusively considered that the simulation skills were limited to driving itself, regardless of whether the driving being simulated was related to a work situation. Without this distinction, the activity of professional driving is reduced to the behaviour of driving a vehicle in a typified traffic situation, pushing the work activity to the background (Hubault, 2011).

In professional driving, specific characteristics directly influence the driver's behaviour and performance, including pressure to perform the task and the demands of customers and managers (Hubault, 2011; Valot, 2007). Without taking this influence into account, both the specific aims of this type of driving - safely moving goods and/or people - and the consequent variabilities, which impact performance and its outcomes, are not given proper consideration. Even the recent review by Goode et al. (2013) on the effectiveness of simulators did not observe this distinction, leading the authors to compare simulationbased training for all types of driving.

The simulators' lack of realism when depicting work or some of the other tasks performed in them (Brook-Carter et al., 2004; Kihl et al., 2006) may be a sign of this gap: the questions and difficulties faced in daily work, the multiplicity of the tasks to be managed in addition to the task of driving itself, and the monotony, fatigue, and psycho-affective mobilisations at work, which play a crucial role in this and any other professional activity, are often ignored. The training programmes that have been studied thus far aim to teach skills to workers based on 
a previously established ideal, whose reference tends to be an abstract driver behaviour rather than a worker acting in a traffic situation. In contrast, we could propose other goals for these training programmes, such as a collective reflection on performing the activity in real-world situations and the difficulties of doing so in a safe and cost-effective manner.

Furthermore, if there is not sufficient theoretical and epistemological discussion on training skills for work situations, then there is even less discussion on how they would form and transform in the activity. The studies reviewed assume that a skill that is acquired in training for the activity will or will not be demonstrated in the activity, hence the challenge of evaluating simulators and their ability to transfer the skills that are developed in them. However, if certain skills are developed in the activity, those developed in simulator-based training would not necessarily be their equal. Training that focuses on a skill in the activity may thus require different configurations from those that focus on what is anticipated of the activity. As an illustration, observe that an initial training that prepares drivers for traffic does not ensure the sufficient control of the vehicle that will be developed in traffic. Similarly, simulators that supposedly facilitate learning transfer by simulating traffic situations may not have been sufficiently designed to simulate the activity of workers because they are still restricted to driver behaviour. Training the actual work activity will require inserting aspects of the activity in a situation into simulation-based training rather than only driving and a typified traffic.

\section{Insufficient Theoretical and Epistemological Conception of Competencies}

Although studies on simulators cite some competencies models, perhaps less focus should be placed on the actual characteristics of competencies and more should be placed on the relationship between them, the operators' level of experience, and the unique situation that mobilises them (Schwartz \& Durrive, 2010). Competencies are not a behaviour, abstract and idealised, achievable regardless of the situation and applicable in any circumstance (Schwartz, 1998). For Schwartz, a competence is an action in a situation that manifests itself through six ingredients that - articulated to a greater or lesser degree, depending on professional experience, the situations on the screen, and the collective relationships that are present there - enable competent action in the activity, always dependent on specific situations. The six ingredients of a competence are as follows:

1. The mastery of the protocols that organise, guide, and/or subsidise actions and that are grounded in scientific, technical, managerial, and linguistic knowledge, among others;

2. The incorporation of a work situation's history, which, in addition to tasks and protocols, is characterised by the series of inevitable singularisations that unfold there, whether they are unforeseen problems, breakdowns, or variabilities of sociotechnical systems, and the productions of knowledge that is developed to confront them;

3. The ability to articulate each situation's protocol-related aspect (tasks and other anticipations) and singular aspect (unexpected) to always make them circular, synergising the first two ingredients;

4. The ability to make the necessary arbitrations between the different requirements that a person has, by mobilising the debate on values that is linked to the debate on norms, imposed and/or established in the activity; this debate on values and norms refers to a permanent renegotiation between the life values and norms of the person acting and the life values and norms of the others; thus, it is the person's ability to assert his/ her own norms when surrounded by others, transforming the environment in which he/ she works into his/her own environment;

5. The activation and duplication of the person's potential, which follows the development of appropriating the milieu as one's own - ingredient 4 - expanding the effects of this appropriation, and the values related to the milieu, on each of the previous ingre- 
dients, to synergise the different aspects of a situation - the protocols, singularisations, debates on values (i.e., ingredients $1,2,3$, and $4-$ and how each person asserts his/her own life norms); and,

6. Making use of the synergies of competencies - always collective and relatively pertinent - that are present in each work situation to be able to act in an environment, through and with others (Schwartz \& Durrive, 2010).

According to this perspective, a competence - whatever it may be - is not the result of definitive knowledge, learned in isolation, and able to be homogenised in a single plane of reference; rather, a competence is a network of relationships among these ingredients. Although these ingredients are - by themselves - heterogeneous, they can be synergised, each articulated uniquely depending on the specificities of the demands and situations, the different types of expertise in play, and the contexts in which they originate. The competence in a work situation is impaired when one of these ingredients cannot be adequately mobilised, even if the activity is being performed competently in another situation. Note that these ingredients are the result of each worker's own history with the activity and inevitably require a permanent transit between the different facets of the activity, be they aspects of protocol, values, or singularisations. In other words, a competence is not objectified knowledge that transfers from a classroom situation to a reality, but rather, it synergises protocol-related knowledge and the history of the situation, personal and collective mobilisations, and values and their impact on a real-world situation.

For example, we observed above that studies on simulators - and how these studies understand driving skills - include little discussion on how the collective dimensions of the activity manifest themselves in this activity and how they can be mobilised by this instrument. To the extent that these dimensions would correspond to ingredient 6 (Schwartz, 1998), not sufficiently exercising these dimensions during training situations would partly explain why behaviours that are learned in training are not transferred to work situations as expected. These same considerations can be applied to each of the other ingredients. Paradoxically, the use of simulators can encourage the exercise of each of these ingredients by varying scenarios for a single skill, an idea that has also been advocated by other authors according to other theoretical references (Goode et al., 2013), which includes the collective dimensions of competencies. Training based on competencies ingredients that are anchored in the work situation can thus help expand the use of simulators.

\section{How to Understand a Work Activity}

It is important to define what a work activity is. The tradition of French Ergonomics recognises the difference between what is prescribed to the worker and what the worker actually does (Falzon, 2007), understanding the activity beyond the simple behaviour of people at work. It also recognises that workers' operative rationalities are part of the activity; these rationalities develop from the experience that is gained through the professional practice, demanded by the inevitable shortcomings of systems, prescriptions, and tasks (Darses, Falzon, \& Munduteguy, 2007).

Based on these more general principles and other theoretical contributions and taking the work activity as a reference while not limiting himself to it alone, Schwartz (2012) develops a philosophical démarche regarding human activity, called Ergology, which can be understood based on the following four postulates.

1. The activity is never a mere execution of what is socially demanded or required but rather the inevitable operative recreation/ regulation of this demand - sometimes in an almost imperceptible act, mobilised by chance situations that are always variable and variant - through the sharing of collective reconceptions of socially imposed knowledge, requirements, and norms and through personal needs and preferences, always unique and incapable of vanishing completely at the moment of action.

2. Through this always insurmountable dis- 
tance, it becomes impossible to fully anticipate another person's activity because what is being anticipated will always be reinvented and recreated; thus, activity is the source of human history.

3. Moving between what is prescribed and what is actually performed is done through the body of each person; this body is biological, social, psychological, and temporary, always in reconstruction.

4. Because the activity is always performed in a different manner, there are always choices being made, which pulls the activity back into a world of values, preferences, social disputes, and history.

Based on these theoretical postulates, we found that the studies reviewed here exclude aspects of the activity that partially justify the meagre effects of the training programmes considered. By demonstrating these aspects, recognising everything from the inevitability of everyday life to the historical and social body, we open up some possibilities for analysis and intervention in future studies.

\section{Ergological Perspectives for the Use of Simulators}

Based on the ergological analyses conducted, and by way of conclusion, some perspectives for training road transport professionals using simulators have been found. The mobilisation of these aspects can contribute to research and practices for training professional drivers using simulators, although this has not yet been considered in Brazilian resolutions on the subject:

1. The development of simulators and training programmes that actually simulate the activity that they seek to develop rather than merely the behaviour of a vehicle in traffic;

2. Collective training involving workers with more and less experience, which increases the possibilities of using instructors without professional experience, contrary to what some have proposed (Brock et al., 2001; Grüneberg \& Schröder, 2012). With these types of collective training, instructors are no longer required to have a very high level of professional knowledge; instead, their task becomes mediating debates, promoting enthusiasm, maintaining the correct attitude, and properly mobilising the theories, methods, and training instruments required by simulators;

3. Training as a possibility for discussion and relationships between different types of scientific knowledge and knowledge that is formed through professional experience. Using instructors with no experience in the profession being trained contributes to this direction if the training involves a collective;

4. Scenarios should concern not only the development of individual skills but also the ingredients of competencies (Schwartz, 1998) that encourage analyses (debriefing), which increase the reflectivity of those involved in these activities. Even in an initial training session, rather than offering simple body training, simulators should serve as mediators of the values and knowledge that are shared by the collective. The professional gesture itself is also considered to be socially produced and transmissible (Clot, 2010);

5. The creation of scenarios that mobilise an analysis of the values underlying activities. Some possible avenues may be scenarios with playful and/or challenging tasks, such as games, which mobilise emotions in the users that approximate those experienced in the actual work situation. From concern with meeting a deadline to the pleasure of driving, a work activity is never completely apathetic, and therefore, a job can never truly be neutral for health (Dejours, 2012); and

6. Training programmes that are designed according to the actual needs of the workers' activity and not a mere analysis of the task (Mitsopoulos-Rubens et al., 2013a). Because it is not a closed package of knowledge that is to be developed, this training possibility - which inevitably involves the end user - may contribute to the development of training programmes and to the instrument itself (Romoser \& Hirsch, 2012). 
Finally, we must warn about the temptation to reduce work accident rates using only professional training. This expectation can limit analyses of accident-related factors, which involve causes beyond the drivers' competencies and personality characteristics. Furthermore, there is evidence of the limited effectiveness of driver training and its effects on reducing traffic accidents (Christie, 2001; Helman et al., 2010). Additionally, certain management practices appear to be more effective in controlling accidents than training (Christie, 2001). Therefore, training should be considered as only one more factor that contributes to road safety.

Future studies should verify the extent to which these suggestions will have a greater effect than those found to date. Regardless, we have shown that the uses of simulators, when anchored in theoretical, epistemological, and methodological reflections, expand their possibilities, which should be taken into consideration by the sectors that are responsible for creating resolutions that regulate professional driver training.

\section{References}

Abbad, G. S., Zerbini, T., Carvalho, R. S., \& Meneses, P. P. M. (2006). Planejamento instrucional em TD\&E. In J. E. Borges-Andrade, G. S. Abbad, \& L. Mourão (Eds.), Treinamento, desenvolvimento e educação em organizações e trabalho: Fundamentos para a gestão de pessoas (pp. 289-321). Porto Alegre, RS: Artmed.

Aginaga-Garcia, J., Iriarte-Goni, X., Pintor-Borobia, J. M., Ros-Ganuza, J., \& San Miguel-Indurain, J. (2013). Implantación de un simulador para la formación de conductores de carretillas elevadoras. Dyna, 88(5), 574-580. doi:10.6036/5581

Blanco, M., Hickman, J. S., Hanowski, R. J., \& Morgan, J. F. (2011). The Commercial Driver. In D. L. Fisher, M. Rizzo, J. K. Caird, \& J. D. Lee (Eds.), Handbook of driving simulation for engineering, medicine and psychology (pp. 241256). Boca Raton, FL: CRC.

Bonch-Bruevich, V. V., Kremez, A. S., \& Chirkov, B. P. (2010). Profession-relevant skills development using psychophysiological trainer. Automation and Remote Control, 71(7), 1461-1464. doi:10.1134/s0005117910070222
Brock, J. F., Jacobs, C., Van Cott, H., McCauley, M., \& Norstrom, D. M. (2001). Simulators and bus safety: Guidelines for acquiring and using transit bus operator driving simulators. Washington, DC: Transportation Research Board.

Brook-Carter, N., Luke, T., \& Parkes, A. (2004, October 4-6). Evaluating the use of a truck simulator for training drivers in safe and fuel efficient driving. Paper presented in European Transport Conference, Strasbourg, France.

Castro, M. N. M., \& Ferreira, L. D. V. (2006). TD\&E a distância: Múltiplas mídias e clientelas. In J. E. Borges-Andrade, G. S. Abbad, \& L. Mourão (Eds.), Treinamento, desenvolvimento e educação em organizações e trabalho: Fundamentos para a gestão de pessoas (pp. 322-339). Porto Alegre, RS: Artmed.

Christie, R. (2001). The effectiveness of driver training as a road safety measure: an international review of the literature. Paper presented in Road Safety Research, Policing and Education Conference, Melbourne, Australia.

Clot, Y. (2010). Poder de agir. Belo Horizonte, MG: FabreFactum.

Darses, F., Falzon, P., \& Munduteguy, C. (2007). Paradigmas e modelos para a análise cognitiva das atividades finalizadas. In P. Falzon (Ed.), Ergonomia (pp. 155-173). São Paulo, SP: Blucher.

Dejours, C. (2012). Trabalho vivo (Vol. 1-2). Brasília, DF: Paralelo 15.

Directive 2003/59/EC of the European Parliament and of the Council of 15 July. (2003, September 10). Official Journal of the European Union, L 226/4.

Dorn, L., \& Stannard, J. (2006). Simulator Performance Differences between experienced and novice bus drivers [Special issue]. Advances in Transportation Studies, 45-52.

Edson, J. M. (2003). Simulator-based equipment operator training. Paper presented in $10^{\text {th }}$ AASHTO-TRB Maintenance Management Conference, Duluth, MN.

Eryilmaz, U., Tokmak, H. S., Cagiltay, K., Isler, V., \& Eryilmaz, N. O. (2014). A novel classification method for driving simulators based on existing flight simulator classification standards. Transportation Research Part C: Emerging Technologies, 42, 132-146. doi:10.1016/j. trc.2014.02.011 
Falzon, P. (Ed.). (2007). Ergonomia. São Paulo, SP: Edgar Blucher

Goode, N., Salmon, P. M., \& Lenné, M. G. (2013). Simulation-based driver and vehicle crew training: Applications, efficacy and future directions. Applied Ergonomics, 44(3), 435-444. doi:10.1016/j.apergo.2012.10.007

Grüneberg, U., \& Schröder, A. (2012). Status of simulator training for professional drivers in Europe. Project SIMTEB: Simulator-based training for European bus drivers. Dortmund, German: European Comunity.

Helman, S., Grayson, G. B., \& Parkes, A. M. (2010). How can we produce safer new drivers? A review of the effects of experience, training and limiting exposure on the collision risk of new drivers. TRL INSIGHT REPORT(S005).

Hubault, F. (Ed.). (2011). Activité de conduite, activité de travail. Toulouse, France: Octares.

Kihl, M., Herring, D., Wolf, P., Finn, M., \& Yang, P. (2007). Snowplow Simulator Training Evaluation: Potential fuel and drivetrain maintenance cost reduction. Phoenix, AZ: Arizona Department of Transportation.

Kihl, M., Herring, D., Wolf, P., McVey, S., \& Kovuru, V. (2006). Snowplow Simulator Training Evaluation. Phoenix, AZ: Arizona Department of Transportation.

Lang, B., Diels, C., Grüneberg, U., \& Helmchen, G. (2011, November 29-30). Lessons Learned from Simulator-Based Training for Bus Drivers. Paper presented in International Driver Behaviour and Training Conference, Paris.

Lindsey, J. T., \& Barron, A. E. (2008). Effects of Simulation on Emergency Vehicle Drivers' Competency in Training. Prehospital and $\mathrm{Di}$ saster Medicine, 23(4), 361-368.

Michon, J. A. (1985). A critical view of driver behavior models: What do we know, what should we do? In L. Evans \& R. C. Schwing (Eds.), Behavior and traffic safety (pp. 485-520). New York: Plenum Press.

Mitsopoulos-Rubens, E., Lenné, M. G., \& Salmon, P. M. (2013a). Driver simulation-based training of heavy vehicle operators: Targeted task analysis and considerations for training design. Paper presented in $7^{\text {th }}$ International Driving Symposium on Human Factors in Driver Assessment, Training, and Vehicle Design, New York.
Mitsopoulos-Rubens, E., Lenné, M. G., \& Salmon, P. M. (2013b). Effectiveness of simulator-based training for heavy vehicle operators: What do we know and what do we still need to know? Paper presented in 2013 Australasian Road Safety Research, Policing \& Education Conference, Brisbane, Australia.

Mooren, L., Grzebieta, R., Williamson, A., Olivier, J., \& Friswell, R. (2014). Safety management for heavy vehicle transport: A review of the literature. Safety Science, 62, 79-89. doi:10.1016/j. ssci.2013.08.001

Moraes, T. D. (2016). O uso de simuladores em atividades de formação para profissionais dos transportes rodoviários. Ciencia \& Trabajo, 18(55), 48-57. doi:10.4067/S0718-24492016000100009

Morgan, J. F., Tidwell, S. A., Medina, A., Blanco, M., Hickman, J. S., \& Hanowski, R. J. (2011). Commercial Motor Vehicle Driving Simulator Validation Study: Phase II. Washington, DC: US Departament of Transportation, Federal Motor Carrier Safety Administration.

Navarrete, J. A. R., Urquiza, E. M., Hernandez, M. V., \& Madrid, M. M. (2004). Generalidades sobre el entrenamiento de conductores y el desarrollo de simuladores de manejo. Sanfadila, Mexico: Instituto Mexicano del Transporte.

Neukum, A., Lang, B., \& Krueger, H.-P. (2003, October 8-10). A simulator-based training for emergency vehicle driving. Paper presented in Proceedings of the Driver Simulation Conference, North America, Dearborn, MI.

Pastré, P. (Ed.). (2005). Apprendre par la simulation: de l'analyse du travail aux apprentissages professionnels. Toulouse, France: Octares.

Pastré, P. (2011). La didactique professionnelle: approche anthropologique du développement chez les adultes. Paris: Presses Universitaires de France.

Pottier, P. (2013). Théories de l'apprentissage et simulation: le point de vue du professionnel de santé-enseignant. In S. Boet, J.-C. Granry, \& G. Savoldelli (Eds.), La simulation en santé: de la théorie à la pratique (pp. 15-24). Paris: Springer Paris.

Rasmussen, J. (1983). Skills, rules, and knowledge; signals, signs, and symbols, and other distinctions in human performance models. Systems, Man and Cybernetics, IEEE Transac- 
tions on, SMC-13(3), 257-266. doi:10.1109/ TSMC. 1983.6313160

Reed, N., Parkes, A. M., Peacock, C., Lang, B., \& Rehm, L. (2007). SCOTSIM: An evaluation of the effectiveness of two truck simulators for professional driver training. Scotland, UK: Enterprise, Transport \& Lifelong Learning Departament.

Reep, A., Staes, L., \& Perk, V. (2013). A qualitative analysis of bus simulator training on transit incidents: A case study in Florida. Jacksonville, FL: National Center for Transit Research.

Resolução Conselho Nacional de Trânsito ${ }^{\circ} 493$ de 25 de junho. (2014, June 6). Diário Oficial da União.

Resolução Conselho Nacional de Trânsito $n^{\circ} 543$, de 15 de julho. (2015, July 20). Diário Oficial da União.

Romoser, M. R. E., \& Hirsch, P. (2012). From lab to real life: A case study in the deployment of advanced driving simulator-based training systems. Proceedings of the Human Factors and Ergonomics Society Annual Meeting, 56(1), 2527-2531. doi:10.1177/1071181312561525

Santana, V., Nobre, L., \& Waldvogel, B. C. (2005). Acidentes de trabalho no Brasil entre 1994 e 2004: Uma revisão. Ciência \& Saúde Coletiva, 10(4), 841-855. doi:10.1590/S141381232005000400009

Schwartz, Y. (1998). Os ingredientes da competência: Um exercício necessário para uma questão insolúvel. Educação \& Sociedade, 19(65), 101140.

Schwartz, Y. (2004). Circulações, dramáticas, eficácias da atividade industriosa. Trabalho, Educação e Saúde, 2(1), 33-55. doi:10.1590/S198177462004000100004

Schwartz, Y. (2012). Expérience et connaissance du travail. Paris: Les éd. sociales.

Schwartz, Y., \& Durrive, L. (Eds.). (2010). Trabalho e ergologia: Conversas sobre a atividade huma$n a$. Niterói, RJ: Editora da Universidade Federal Fluminense.
Schwartz, Y., \& Echternacht, E. (2009). Le corps-soi dans les milieux de travail : comment se spécifie sa compétence à vivre? Corps, 1(6), 31-37. doi:10.3917/corp.006.0031

Strayer, D. L., \& Drews, F. A. (2003). Simulator training improves driver efficiency: Transfer from the simulator to the real world. Paper presented in $2^{\text {nd }}$ International Driving Symposium on Human Factors in Driver Assessment, Training and Vehicle Design, Salt Lake City, UT.

Tarr, R. (2005). Simulation as a Tool for Enhancing Commercial Driver Skills: A Systematic Approach to Tailored Training. Paper presented in Driving Simulation Conference, Orlando, FL.

Tarr, R., \& Whitmire, J. D. (2008). Simulation as a Tool for Enhancing Commercial Driver Skills and Recertification: Follow-On to the Virtual Check Ride System. Tallahassee, FL: Florida Department of Transport, Motor Carrier Compliance Office.

Uhr, M. B. F., Felix, D., Williams, B. J., \& Krueger, H. (2003, October 8-10). Transfer of Training in an Advanced Driving Simulator: Comparison between Real World Environment and Simulation in a Manoeuvring Driving Task. Paper presented in DSC North America 2003 Proceedings, Dearborn, MI.

Valot, C. (2007). O transporte, a segurança e a ergonomia. In P. Falzon (Ed.), Ergonomia (pp. 573586). São Paulo, SP: Edgar Blucher.

Victor, T., Hickman, J., Camden, M., Jarlengrip, J., Larsson, C., Morgan, J., ...Toole, L. (2011). U34: Driver Distraction: An Inattention-Mitigation Component for Behavior-Based Safety Programs in Commercial Vehicle Operations (IM-BBS). Washington, DC: National Transportation Research Center. 